\title{
Historical Institutionalism and EU-Turkey Relations: Path Dependence and Critical Junctures in the Accession Process
}

\author{
Gülay Icoz and Natalie Martin
}

\subsection{INTRODUCTION}

Historical institutionalism (HI) returned to the fore in the early 1990s as part of the new institutionalism group of theories, which also includes rational choice institutionalism (RCI) and sociological institutionalism (SI) (Hall \& Taylor, 1996). HI is distinguished by its emphasis on processes over time, rather than examining snapshots, or moments in time, and theorizes two main concepts: stasis and change. Stasis, or why things stay the same, is attributed to 'path dependence', whereby what comes after is dependent on previous events (Sewell, 1996). Change is attributed to events of varying magnitude originating either within the institution or outside of it. Accordingly, HI considers whether the change process is one of 'punctuated equilibrium', implying a series

\footnotetext{
G. Icoz

University of London, London, UK

N. Martin $(\bowtie)$

University of Nottingham, Nottingham, UK

e-mail: Natalie.Martinl@nottingham.ac.uk

(C) The Author(s) 2021

W. Reiners and E. Turhan (eds.), EU-Turkey Relations, https://doi.org/10.1007/978-3-030-70890-0_4
} 
of smaller scale events (Krasner, 1984), or fewer, but more significant 'critical junctures', as the mechanism that may sway path dependence off course (Cappoccia \& Kelemen, 2007: 343-344). It is argued here that the Turkish accession process is a prime candidate for using this temporal approach-not least because EU-Turkey relations have existed since 1959, and hence, there is a rich process to study that would benefit from taking politics ' $[\ldots]$ as a movie rather than a series of individual snapshots' (Pierson, 2004: 1).

This chapter argues that HI is apposite to Turkey's EU accession process because it asks questions that cannot be answered by snapshot theories. ${ }^{1}$ The political landscapes of the EU and Turkey are complex and diverse, and mere snapshots cannot encompass this complexity. It argues that EU-Turkey relations exist-and have endured-for security reasons. These reasons began as strategic issues, during the Cold War, but have developed into a broader understanding of security since the 1990s to encompass human and energy security as well (among others) (Buzan et al., 1998). Moreover, the relationship is highly path-dependent for both material and ideational reasons: materially, the strategic security value of Turkey has endured, and ideationally, the liberal democratic reputation of the EU was staked upon it (Martin, 2015a: 109). The EU felt obliged to honor its commitments, pacta sunt servanda, regarding enlargement firstly from Eastern European states and then Turkey.

This chapter concentrates on the period from 2005, when Turkey's accession negotiations with the EU began, to 2020. It will identify the path-dependent nature of the enduring relationship and the points at which endogenous and exogenous changes have influenced events. These points are characterized as 'critical junctures' (rather than punctuated equilibrium) and fall into two categories: those which have hindered the process and those which have expedited it. In the first category is the succession of member states which vetoed the opening and closing of the acquis communautaire chapters between 2006 and 2009, which led to a stalemate in the accession process. In the second, we see how the Arab Spring rejuvenated Turkey's geostrategic value and its moribund accession process. It prompted, at least partly, the May 2012 Positive Agenda initiative to kick-start the accession process. The Arab Spring and the subsequent civil war in Syria also contributed to the refugee crisis of

\footnotetext{
${ }^{1}$ For instance, other forms of institutionalism and theories such as Liberal Intergovernmentalism (see Moravcsik, 1999; Tsarouhas, Chapter 2).
} 
$2015 / 16$, which further expedited the process and led to the AnkaraBrussels joint statements of November 2015 and March 2016 (the latter also known as the EU-Turkey refugee 'deal'). Both statements attempted to breathe life into Turkey's accession process to procure wider Turkish goodwill and cooperation. However, any progress made was then negated by the backlash to deteriorating human rights following the July 2016 attempted coup d'état (see also Turhan \& Reiners, Chapter 1).

The net effect has been that neither attempts to sideline Turkish accession (through vetoes and opposition) nor kick-start it (from geostrategic need) have been effective-the process has continued regardless of positive or negative influences displaying resilient path dependence. This chapter will first outline the theory of historical institutionalism, placing it in the context of wider theory and metatheory, and exploring its relevance to Turkey and the EU. It will then analyze the nature of the critical junctures identified and how they relate to the underlying path dependence of Turkey's accession process. Lastly, it will assess the explanatory value of HI and suggest directions for future research.

\subsection{Historical Institutionalism}

\subsubsection{The Role of Time in Political Science and International Relations}

Historical institutionalism has fallen between the disciplinary silos of political science and International Relations (IR), which have very specific and individual theoretical approaches. Moreover, it has also been caught between metatheoretical debates in IR-positivism and post-positivism. The result has been that HI remains a niche theoretical approach that often gets lost within wider disciplinary disputes. However, this chapter will argue that $\mathrm{HI}$ has a valuable contribution to make to European studies, EU-Turkey studies and Turkish studies in explaining EU-Turkey relations because of its emphasis on temporality. As Steinmo (2008) has argued, what we now call HI is actually a form of historical description and not a new phenomenon. Within IR it was undermined by the influence of behavioralism in the 1950s and the subsequent development of positivist theories. It was the need to conform to the positivist norms of statistical measurement which led to an overemphasis on 'snapshot' approaches rather than the processes over time, which are harder to quantify because they retain context and explanatory power (Hay, 2002). 


\subsubsection{New Institutionalism}

HI came into the theoretical lexicon of political science and IR in the early 1990s. It was coined by Steinmo et al. (1992), who drew on the macro-historical approaches of comparative political economy (Skocpol, 1979) and placed HI as one of the three variants of new institutionalism. Steinmo et al. applied the macro-historical emphasis to much shorter timescales and focused on the processes of stasis and change within institutions. As such, this approach still largely conformed to the contemporary positivist norms within IR and was couched within deductivist terms, seeing 'institutions' as either dependent or independent variables (Steinmo et al., 1992: 15).

It was further developed by Hall and Taylor (1996), who placed HI alongside RCI and SI as ways of theorizing institutions in general. Each strand of new institutionalism differed in its approach to the study of institutional policy and decision-making. RCI applied rational choice theory to institutional settings to examine the role of institutions in tempering the self-interested inclination of members (Steinmo et al., 1992). SI, on the other hand, incorporated the then-nascent approach of social constructivism to look at institutional decision-making from a cultural perspective (Hall \& Taylor, 1996), which also taps into the logics of consequences and appropriateness (March \& Olsen, 1984).

HI emphasized the importance of looking at more than snapshots of time, as both RCI and SI were inclined to do. Around this time, it was common for RCI to be characterized as a positivist approach and SI as an interpretivist approach, with HI characterized as a hybrid or eclectic approach (Hall \& Taylor, 1996). However, it is argued that HI is a sui generis approach rather than as a compromise to solve a metatheoretical conundrum. As analyzed by Pierson and Skocpol, its defining characteristic and explanatory value lie in its emphasis on taking a long-term view:

Without the kind of attentiveness to temporally specified process $[\ldots]$ important outcomes may go unobserved, causal relationships may be misunderstood and valuable hypotheses may never receive consideration. (Pierson \& Skocpol, 2002: 699)

Arguably, because of straddling disciplinary and metatheoretical divides, the concept of HI is 'woolly' and ill-defined (Rixen \& Viola, 2016). Neither its definition nor its metatheory are consistent between advocates, 
and HI would benefit from 'theoretical refinement' (Pierson, 2004: 139142). However, the eclecticism of $\mathrm{HI}$ is a strength and is only problematic if judged by positivist standards. Instead, we argue that HI can be both deductive or inductive: hypotheses can relate to a time span, or evidence can be assessed over a time span. Furthermore, HI can also address material factors, for instance, written policies, or ideational factors, such as norms and values. Accordingly, it can use an array of data sources-quantitative, qualitative, or both (although usually qualitative)-because its defining feature within these broad parameters is time. As Pierson persuasively argues, although it has emerged as part of new institutionalism, HI is as concerned with history as it is with institutions:

[HI] scholarship is historical because it recognizes that political development must be understood as a process that unfolds over time. It is institutionalist because it stresses that many of the contemporary implications of these temporal processes are embedded in institutions, whether these be formal rules, policy structures, or social norms. (Pierson, 1994: 29)

HI scholars such as Pierson and Skocpol (2002) emphasize three key elements of HI: big real-world puzzles, temporality, and context-and this is HI's uniqueness. However, this is not a zero-sum game but merely an assertion that different theories ask different questions. Therefore, which one is chosen will depend on the question being asked. With regard to Turkey's EU accession process, HI can illuminate processes over time in a way in which RCI and SI cannot. HI is able to illuminate processes of change-or non-change-and, hence, more recently has come to be seen as a 'useful tool' in the study of institutions (Rixen \& Viola, 2016: 4 ) and specifically the EU-Turkey accession process.

\subsubsection{Stasis and Change}

If the defining characteristic of $\mathrm{HI}$ is its attention to processes over time, then the tools it uses are those that look at the processes of stasis and change. Furthermore, HI examines the cause of the change in question, whether it is incremental or sudden. The primary tool for examining policy inertia, i.e., stasis, is 'path dependence', defined by Sewell as a concept in which '[...] what happened at an earlier point in time will affect the possible outcomes of a sequence of events occurring at a later 
point in time' (Sewell, 1996: 262-263). Similarly, Rixen and Viola (2016: 12) have characterized path dependence as '[...] a specific kind of process that is set in motion by an initial choice, decision, or event, which then becomes self-reinforcing'. Policy decisions become fixed because funds may have been invested or reputations are staked on their success; therefore, reversing the policy is more costly than continuing with it.

Path dependence therefore can be defined as the process in which what comes after depends on what went before. However, its simplicity is deceptive, because there are various reasons why path dependenceand therefore policy stasis-exists, and not all of them are present every time. These reasons are sunk costs, the notion of 'lock-in' or institutional inertia, and sequencing, which argues that some things may not happen because of previous decisions in which things may have happened if the previous event had not have happened (Cappoccia \& Kelemen, 2007: 342). This contingent aspect of the concept of path dependence, therefore, has contributed to the criticism of the theory's 'woolliness'. As Mahoney has argued: 'Discussions of path dependence have been hampered by a basic problem; analysts often lack a clear understanding of the meaning of path dependence' (Mahoney, 2000: 535). The best way to understand path dependence is to acknowledge the influence of past decisions on what may follow and be aware that there may be several reasons for this. The factors involved should be established case by case. For this reason, process-tracing (George \& Bennett 2005; see also Collier, 2011 ) is an oft-used methodology with this approach:

The aim has been to demonstrate the existence and effect of historical legacies in the political processes and institutions of the present. [...] For them, (HIs) [...] history matters; to understand the present is to understand how it has evolved from the past and to trace the legacies of that evolution. (Hay, 2002: 136)

Another recurrent criticism of $\mathrm{HI}$ is that its emphasis on path dependence precludes explanations of change. In other words, '[...] although it is well suited for explaining the persistence of policies, it is much less capable of explaining change in those same policies' (Peters et al., 2005: 1288). This criticism is countered by the concept of 'critical junctures', first used by Collier and Collier (1991).

Inevitably perhaps, the notion of a 'critical juncture' is also 'woolly': it can be seen as the start of a path-dependent process or the result 
of exogenous factors that cause change to develop in a path-dependent process. Alternatively, it can be viewed as a necessarily arbitrary point or a convenient theoretical device to avoid going ever farther back into history or 'infinite explanatory regress into the past'. The critical juncture is crucial to HI because ' $[. .$.$] after this [...] major alternative development$ trajectories are increasingly closed off' (Mahoney, 2001: 8).

Cappoccia and Kelemen urge 'caution and clarity' in the approach. They define 'critical' through 'probability jump' and 'temporal leverage'. That is increased likelihood-but not proof-that choices made at the given time will affect the outcome by triggering a path-dependent process 'which constrains future choices'. Critical junctures must also be anchored to a unit of analysis as they are relative to time and space rather than absolute concepts. What is a critical juncture for one policy area may not be for another-or it may be at another time. These junctures are also relative to each other: '[...] the duration of the critical juncture must be brief relative to the duration of the path dependent process that it initiates' (Cappoccia \& Kelemen, 2007: 350).

\subsubsection{Historical Institutionalism and Turkey's EU Accession Process}

What gives HI theoretical value is that it asks different questions than the other 'institutionalisms' as well as provides different theoretical perspectives due to its emphasis on temporality. When applying this to the case of Turkey's EU accession process, we can ask what periods of stasis or change have occurred since accession negotiations were opened in 2005 and why these may have occurred. Additionally, it is useful in discussing what the sources of stability or change may be, and this may help with future predictions about the process. These sources or triggers can be internal, to the country or institution in question, or external (Cortell \& Peterson, 1999: 185). External (global) triggers include war, pandemic, geopolitical conflict, changing balance of power within institutions, technological change, and macroeconomic change; internal triggers include revolution, civil war, military coups, elections/changes of government, economic growth rate, demographic change, and social movement/conflict (see also Turhan \& Reiners, Chapter 1). In this case, we will consider the strength of the path dependency of the accession process and the nature of the various critical junctures it has reached-namely, member states vetoing 
the opening and closing of the acquis communautaire chapters for Turkey between 2006 and 2009, the consequences of the Arab Spring and the illiberal nature of governance in Turkey.

Stasis and change can also be the result of individual action or agency (Gourevitch, 1986: 236). At critical junctures, individuals have a greater ability to influence policymaking. This has two consequences: (1) the range of plausible choices open to powerful political actors expands substantially, and (2) the consequences of their decisions on the outcome are potentially much more momentous (Martin, 2019). We believe paying attention to what politicians in Turkey and EU leaders do during these critical junctures is also crucial in explaining what impact the critical junctures have had on the accession process. For instance, emphasizing how politicians, such as then Turkish EU minister, Ali Babacan, or EU Enlargement Commissioner, Štefan Füle, present opportunities to enact new plans and realize new ideas during the critical junctures (Gorges, 2001: 156), we can explore if any critical juncture in the accession process has translated to opportunities for new ideas or new plans.

The analysis below concentrates on the accession process from the opening of negotiations in 2005 until 2020. It considers the points of change already outlined and the impact they may have had on the accession process. It argues, the accession process remains in a state of 'managed containment' (Martin, 2019) that has been constant since 2005. The points of change, or critical junctures, have been the result of internal EU dynamics, in particular opposition to the Turkish case, and external geopolitical factors, namely the Arab Spring. These have slowed down or sped up the process at various points in time; but overall, very little has changed due to Turkey's poor record of liberal democracy.

\subsection{Turkey's EU Accession Process: Stasis and Change Since 2005}

The Turkish case is the longest standing accession process in the EU. Ankara's first approach to join, what was then the EEC, was in 1959 and an Association Agreement was signed in 1963. The delay was the result of the intervening coup d'état in Turkey in which the Prime Minister, Adnan Menderes, and others, were executed by the Kemalist military. The illiberality on display ruled out imminent membership for Turkey but the Association Agreement enabled the member states to maintain Ankara's 
goodwill within 'Europe' and, crucially, within NATO. Although very separate institutions, Brussels had come under some pressure from the USA not to alienate Ankara for these hard power geostrategic reasons (Martin, 2015a: Chapter 1). Even after the Cold War ended, Washington used possible EU candidacy as an incentive for democratization in Turkey because that was deemed to be in NATO's interests. With the UK as a proxy within the EU, the USA encouraged the EU-Turkey Customs Union of 1995 and the candidacy offer made at the Helsinki European Council in 1999. Once the offer had been made Turkey was then able to 'sufficiently fulfill' enough of the Copenhagen criteria, with some nudging from the UK, for the EU to feel obliged, pacta sunt servanda, to honor its commitment and open accession negotiations in 2005 (Martin, 2015b).

Hence, Turkey was admitted into the European sphere, as an aspirant member, and subsequently a formal candidate, because of its security value in different ways at different times. This security value became a driver of the enduring path dependence and is still evident in Turkey's accession process. Since the beginning of the Cold War it has been too valuable strategically to cast adrift from 'Europe' but not quite valuable enough for this to override the liberal democratic criteria of the EU. This 'ying' and 'yang' dynamic, between security and liberal identity, is what has maintained the process in stasis despite several junctures over time where it may have changed by going forward-or ending altogether.

\subsubsection{Vetoes}

As agreed at the European Council meeting in December 2004, the EU opened accession negotiations in 2005 by adopting the Negotiation Framework (European Commission, 2005), which set out principles governing the negotiations on the thirty-five chapters of the acquis communautaire. ${ }^{2}$ However, difficulties centered on Turkey's reluctance to recognize the sovereignty of Cyprus and the legitimacy of its shipping flag soon emerged. Consequently, in December 2006 the Council agreed to block the opening of eight chapters, covering policy areas relevant to Turkey, as well as the closure of other chapters due to the problems between Turkey and the Republic of Cyprus (Council of the European Union, 2006). Relations with Cyprus were (and remain) highly sensitive

\footnotetext{
${ }^{2}$ For a comprehensive overview of the accession negotiations and the status of individual chapters see also Lippert (Chapter 11).
} 
in Turkey, especially after the 2004 referendum (Hannay, 2005), and the EU's actions made Turkey's EU accession dependent on the resolution of the Cyprus issue, which was highly unlikely. The EU negotiator Ali Babacan reacted by accusing the EU of discrimination:

[...] for Turkey we have found out that the opening of the chapters and closing of the chapters could be influenced by reasons which are of a very political nature. [...] Now we cannot open eight chapters, we cannot close any of the chapters until the Cyprus issue is resolved [...]. (Parker \& Thornhill, 2007)

The incident also negatively impacted Turkish public opinion of the EU as the Cyprus issue was seen as evidence of prejudice against Turkey as a Muslim country. This loss of trust affected the future of the accession process.

While the Turkish authorities were still absorbing the effects of the December 2006 veto, French President Nicholas Sarkozy blocked the opening of Chapter 17, 'Economic \& Monetary Policy', in June 2007. Furthermore, Sarkozy was highly undiplomatic when justifying this block, stating, 'I do not believe Turkey has a place in the European Union' (Parker et al., 2007). Following this, France blocked another four in December 2007 and a further six in December 2009 (Turhan, 2016: 469). However, regardless of the reaction to Sarkozy's comments and the subsequent Cypriot actions, the accession process remained intact, albeit dormant. It is thus pertinent to ask why the accession process endured these vetoes from 2006 to 2009 . There are two interconnected points to answer this question. The first is that while both the Council and Nicholas Sarkozy vetoed the opening of negotiations on certain chapters, they did not suggest calling off the accession process. Secondly, since the Turkish authorities did not drastically react to the European Council's veto position, apart from an expression of disappointment, the course of action did not change.

\subsubsection{The 'Positive Agenda'}

Hence, although the initial period of accession negotiations was turbulent and little progress was made, the negotiation process continued despite the vetoes. Subtracting the 2006 Council veto (eight chapters), then the 
French veto (five chapters), and finally Cyprus' veto (six chapters), there were only three chapters left to open.

In May 2012, Commissioner for Enlargement and European Neighborhood Policy, Štefan Füle, and Turkish Minister for European Affairs (and then Chief EU negotiator) Egemen Bağıs, launched the 'Positive Agenda' in Ankara. The aim of this process was to keep Turkey's accession process alive and put it back on track after a period of, in their words, 'stagnation'. The Positive Agenda was described as '[...] a new way of looking at the accession negotiations. It is the new way we communicate and interact with each other. It is the way how we look at each other as two equal partners' (European Commission, 2012). It was designed not to replace but to complement the accession process and give it renewed impetus (Paul, 2012). The initiative outlined policy areas in which Turkey was expected to carry out reforms:

- Fundamental human rights

- Visa, mobility, and migration

- Trade

- Energy

- Counterterrorism

- Foreign affairs.

Working groups were established on eight chapters designed to accelerate Turkey's process of alignment with EU policies and standards in those areas. The Positive Agenda, which was Füle's personal initiative (Paul, 2012), increased the scope for dialogue between the EU and Turkey and opened doors for further integration.

While the Positive Agenda was treated as an opportunity to restart the process by both sides after the vetoes and years of stagnation, the accession process soon returned to a stalemate due to the deterioration of human rights in Turkey including press freedom (Committee to Protect Journalists, 2012). The accession process was further stymied when Ankara suspended contact with the EU while Cyprus held the rotating EU presidency from July to December 2012. Ankara had consistently refused to recognize the sovereignty of Cyprus due to the sensitivity of the reunification issue and had made its views clear regarding the legitimacy of Nicosia assuming the rotating presidency role for the EU. When this transpired regardless, Ankara was implacable. Turkish Deputy Prime 
Minister, Beşir Atalay, said: '[...] we will freeze our relations with the EU. We have made this announcement, as a government we have made this decision. Our relations with the EU will come to a sudden halt' (Dombey, 2011).

This freeze put the accession process back on hold, and the Positive Agenda stalled. When Füle stepped down from being European Commissioner for Enlargement and European Neighborhood Policy in October 2014, the Positive Agenda fizzled out. Although the accession process itself endured, the legacy of the Positive Agenda was not positive: Turkey continued to believe the EU did not want Turkey as a member, and the EU was concerned by the Turks' implacability over Cyprus.

\subsubsection{The Refugee Crisis}

It took the refugee crisis of 2015-2016 to bring the accession process back to life. The EU had actually begun discussing migration matters with Turkey in 2013, and France subsequently removed its veto over Chapter 22, 'Regional Policy and Coordination of Structural Instruments'. In December 2013, the European Commission and the Turkish authorities had signed the EU-Turkey Readmission Agreement, which initiated the EU-Turkey Visa Liberalization Dialogue (VLD) (European Commission, 2014; see also Kaya, Chapter 14). This agreement aimed to limit the influx of irregular migrants entering the EU through Turkey and return any irregular migrant who is found to have entered the EU through Turkey. In return for implementing this agreement, the EU promised to begin an EU-Turkey VLD to progress toward eliminating the visa obligation currently imposed on Turkish citizens travelling to the Schengen area for short-term visits. The VLD had a positive impact on the Turkish public opinion about the EU, which had been lukewarm previously. In 2013 only $45 \%$ believed membership would be a good thing, while in 2014 this had risen to 53\% (German Marshal Fund, 2014). Since Turkish people had waited for a visa-free regime for several years, they regarded the Readmission Agreement as part of the price to pay. However, many Turkish officials still regarded Brussels with suspicion as a result of the vetoes from 2006 to 2009 .

So, while some progress had already been made in implementing the Readmission Agreement, the migration issue in Spring/Summer 2015 brought the matter to a head following a sudden increase in the number of people moving through Turkey into the Schengen area. This sentiment 
was particularly acute following the death of the two-year-old refugee, Aylan Kurdi, in September 2015 and the heartbreaking photograph of his body on a Turkish beach (Smith, 2015). The need to procure Turkish cooperation to manage the refugee issue became acute and forced the EU to offer incentives on accession. In the November 2015 EU-Turkey Statement (European Council, 2015), which followed several weeks of negotiation, the EU and Turkey agreed to initiate regular EU-Turkey summits (see also Turhan \& Wessels, Chapter 8), to 're-energize' the accession process and open Chapter 17 of the acquis communautaire. Additionally, there was the promise of visa liberalization, 3 billion euro of humanitarian aid and the Joint Action Plan on 'migration management' to curtail the number of people reaching Greece from Turkey (Turhan, 2016). The Commission also delayed the 2015 progress report, which highlighted a negative trend in respect for the rule of law and fundamental rights, until after the November general election in Turkey.

A further EU-Turkey Statement was agreed in March 2016 under which there would be an 'acceleration' of visa liberalization and irregular migrants would be returned to Turkey in exchange for migrants in Turkey to go to the EU. An additional 3 billion euro was agreed for humanitarian aid and work to 'upgrade' the Customs Union was 'welcomed' by both sides (European Council, 2016). Moreover, the accession process would be re-energized, again, with the opening of Chapter $33^{3}$ and preparatory work on other chapters would 'continue at an accelerated pace' (European Commission, 2016). The opinion in Brussels and other member state capitals was that these measures would not have been agreed without the imperative of the migration situation. The two joint statements (of November 2015 and March 2016) and the March 2016 deal were achieved despite Turkey's deteriorating human rights record (Esen \& Gümüşçü, 2018), which was the reason for considerable cynicism.

The March 2016 refugee 'deal' was criticized both for its inherent illiberality and its reliance on the illiberal human rights regime in Turkey. ${ }^{4} \mathrm{On}$ the second point, the United Nations High Commissioner for Refugees and Amnesty International opposed the plan to return migrants back to

\footnotetext{
${ }^{3}$ Chapter 33 of the acquis communautaire refers to financial and budgetary provisions.

${ }^{4}$ It was also criticised on the grounds that it relied on an unlikely solution to the Cyprus problem to make it work (see Martin, 2019).
} 
Turkey because of its human rights record and the fairness of its asylum system (Pitel, 2016). Amnesty International was also scathing of the EU, claiming it was 'shirking its responsibility to people fleeing war and persecution' by using Turkey as a 'border guard' (Amnesty International, 2016). After the first joint statement, in November 2015, Marc Pierini, the former EU Ambassador to Ankara, had said the EU's willingness to reach such agreements with Turkey in spite of Ankara's human rights record was 'EU Realpolitik at its worst'. Pierini attributed it to 'political panic' and said the EU had gone to Erdoğan 'on our knees' and 'now he is playing us' (Pitel \& Beesley, 2015). A senior EU diplomat said Erdoğan had gone from being 'untouchable' in the EU in the summer of 2015, to being the 'dinner companion of choice' of the EU's three presidents (of the Parliament, Commission, and the European Council) as well as that of German Chancellor Angela Merkel in the autumn (Barker, 2015). The migration issue should therefore be seen as an exogenous shock to the EU-Turkey relations which kick-started the accession process temporarily but undermined the liberal credentials of the EU (Martin, 2018).

\subsubsection{Authoritarian Drift}

Hence the accession process slumped after the vetoes and was revived, but only temporarily, by the Positive Agenda. It took the geopolitical imperative of the refugee crisis to bring both sides back to the table primarily because the EU felt it had no other option at that time. However, once the refugee situation stabilized, the accession process returned to stasis, this time because human rights in Turkey deteriorated even further following the July 2016 coup d'etat attempt. Moreover, the mainstay of the March 2016 deal, visa liberalization, had not been forthcoming because Turkey had failed to meet the condition of liberalizing its counterterrorism legislation.

Whilst Turkey had been 'drifting' toward authoritarianism prior to 2016, the scale of detentions, many on spurious grounds of 'terrorism' (Martin, 2018), after the attempted coup d'état, provoked hostility within the EU despite the need to maintain the refugee 'deal'. Dimitris Avramopoulos, the EU's Migration Commissioner, said: 'We have always been clear with our Turkish partners on visa liberalization-if Turkey wants visa liberalization, all conditions must be met' (Pitel \& Brunsden, 2016). The European Council President at that time, Donald Tusk, said the decline of liberal democracy in Turkey jeopardized its accession 
prospects: 'We want to keep the doors open to Ankara, but the current reality in Turkey is making this difficult' (Barker et al., 2017). Austria, a longstanding critic of Turkey's accession, called for membership talks to be frozen (Beesley, 2016), and Germany also voiced misgivings about human rights in Turkey (Wagstyl \& Chazan, 2017). Erdoğan's response was to call the EU member states' bluff: he accused them of discriminating against Turkey and dared them to 'do the necessary thing' if they could no longer tolerate working with his country (Pitel, 2017).

In 2019, the European Parliament (EP) voted to suspend accession talks with Turkey (European Parliament, 2019) due to concerns about human rights and civil liberties, political pressure on the judiciary, and the unresolved territorial disputes with Cyprus and other neighboring countries, which were also stressed in the 2019 country report of the Commission (European Commission, 2019). Although EU governments have the final say in any suspension, the EP's decision was a serious setback for accession negotiations. The Turkish government dismissed the vote as 'worthless, invalid and disreputable' (Reilhac, 2019) but further problems emerged in Summer 2019 over Cyprus. In July, Turkish Foreign Minister Mevlüt Çavuşoğlu said that his government was suspending the Readmission Agreement with the EU due to the stalemate over visa liberalization following the 2016 refugee 'deal' (Candau, 2019). There has also been controversy over the sovereignty of gas reserves found in the Eastern Mediterranean and Turkish drilling activities (Pitel, 2019), which resurrected Turkey's issues with Cyprus and led to several sanctions by the Council, inter alia, the suspension of the Association Council and further meetings of the EU-Turkey high level dialogues for the time being (Council of the European Union, 2019). So, in summary, the refugee crisis was an opportunity to progress the accession process, but this did not materialize because of the authoritarian drift in Turkey which worsened further following the attempted coup in July 2016. Since then, the situation has continued to flounder and has been complicated further by a dispute over gas reserves with Cyprus.

\subsection{The Accession Process Goes on (AND ON?)}

Turkey's EU accession process began as a result of a security imperative during the Cold War and has demonstrated ongoing path dependence for related reasons. Even after the Cold War ended, Turkey retained geostrategic significance for the EU and NATO, including during the 
Balkan wars, the Iraq war, and more recently, the Syrian civil war and the parallel migration crisis. It is argued here that since accession negotiations were opened in 2005, the accession process has been tested and thrown off course at various times by different events; however, the process has also shown remarkable resilience, as a result of path dependence. HI illuminates this temporal process, unlike comparable theories such as RCI, SI, or liberal intergovernmentalism. While RCI, SI, and liberal intergovernmentalism may have valid points to make about, say, the December 2004 European Council or the EU-Turkey Statements in 2015 and 2016, they consider these events as snapshots rather than as part of a long-term process. They simply do not ask these questions; they ask other types, of equally valid questions, but not questions of temporality.

Since 2005, there have been several points of change, both pushing and constraining accession, which we have identified as critical junctures. The accession process has been influenced by the changing constellation of state leaders within the EU and their views on Turkey as well as the consistent hostility of member states such as Austria and Cyprus to the Turkish case. However, the EU's need to placate Turkey over security issues and maintain wider cooperation has boosted Turkey's accession progress. While vetoes have acted as a deterrent to accession, security issues have been an incentive for Turkey's accession. However, neither has sustainably impacted the actual accession process.

Various actors' vetoes on opening and closing chapters between 2006 and 2009 deterred the Turkish government from continuing with liberalizing reforms as it lost confidence in the EU's sincerity about accession. It should be noted that, at this time, Turkey's withering accession process was convenient for several member states which had not been wholehearted supporters of opening negotiations in 2005 but had felt cornered into agreeing to it because of the pacta sunt servanda effect. However, as has been outlined, whilst the accession process was moribund after 2006, the process itself continued as a bureaucratic entity. Conversely, the Positive Agenda was hailed as a 'new beginning' for EU-Turkey relations but never overcame the twin problems of Turkey's declining human rights record and the legacy of its Cyprus relationship. It failed to kick-start the process, and no tangible progress was made, but accession continued as before within the EU bureaucracy for the same reason: security. Turkey's covert involvement in the Syrian civil war was an open secret even then. Turkey's overt relevance to both the future of the Assad regime and the Kurdish issue was obvious, and this was enough to maintain relations. 
The refugee crisis in 2015 was another factor which kick-started accession process in spite of the EU's liberal credentials. While the 2016 refugee 'deal' was signed before the further deterioration of human rights following the attempted coup in July of that year, it was nevertheless signed amidst the ongoing persecution of journalists and academics as well as serious human rights issues in eastern, Kurdish areas of Turkey such as Cizre and Nusaybin (United Nations, 2017). The EU sealed the deal despite challenges to its liberal principles in the face of rising populism and opposition to immigration in some member states. However, the further deterioration of human rights provided cover for various member states to backtrack on the visa aspect, and yet, like before, the accession process itself remained intact. Overall, accession has been strongly pathdependent, based on a security imperative that has endured, but has failed to advance because of human rights concerns.

\subsection{Conclusions}

HI's raison d'être is to highlight the existence and significance of processes over time. Analyzing Turkey's accession process through this approach, it has been argued that the path-dependent nature of Turkey's EU accession process has endured for broadly defined security reasons. Turkey became an applicant and a candidate because of security considerations and the process has continued for broadly similar reasons in a broadly similar way meaning the status of Turkish accession in 2020 is not that different to 2005. Overall, the positive influence of security concerns in forwarding the process has been balanced by the negative influence of Turkey's poor human rights record. Hence, the accession progress has been driven by its security value, but this has never been strong enough to overcome the residual misgivings (and hostility) from the EU side to translate into real accession progress. Turkey has progressed more when its perceived security value was higher-and the converse is also truebut the net effect, over time, is managed containment. Overall, it has retained its place as a potential candidate of the EU, for security reasons, but has never maintained sustained and meaningful progress. The security reasons have not been enough to override the underlying hostility of several member states who have been able to fall back on 'human rights' to put the brakes on. The significance for $\mathrm{HI}$ is that it is these patterns, of 
stasis and change, over time which would not be revealed by other theories within political science or IR because they do not ask such temporal questions.

Nevertheless, the value of HI could also be viewed as a weakness as it does not address the details of the other institutionalisms and liberal intergovernmentalism, among others. It has neither the forensic rigor of RCI, nor the ideational freedom offered by the interpretivism of SI. In taking such a long-term view, $\mathrm{HI}$ inevitably has to make generalizations, leaving it susceptible to accusations of 'woolliness'. In addition, HI does not address the minutiae of wider issues inherent within the argument presented here. For example, the locus of this path dependence argument is the 'security imperative': this is not part of HI theory per se but is incorporated into it instrumentally when it helps explain the concept of path dependence. A similar logic applies to the notion of liberal democracy which is acting as a counterweight to security in this path-dependent process. HI uses these concepts to explain the temporal processes but does not speak to them directly and does not address the issues of metatheoretical commensurability.

However, what HI does do is identify patterns over time. The future for $\mathrm{HI}$ is to streamline the metatheory and extricate HI from the metatheoretical no-mans-land so it can develop on its own terms and incorporate the 'thick description' and context that was stripped out by the dominance of positivism. It is suggested that the development of HI within a critical realist metatheory would be a productive way forward (Bhaskar, 1989; Wight, 2006). Tighter definitions of the change mechanisms would also help it lose its 'woolliness'. As Rixen and Viola (2016) argue, HI has much to offer to the study of institutions in general and EU-Turkey relations in particular.

Lastly, it is likely that the path dependence of Turkey's EU accession process will survive the authoritarianism of the ruling Justice and Development Party (AKP) and the Erdoğan government because of the ongoing security imperative. This has underpinned the path-dependent nature of the relationship since the beginning, and it has been further galvanized by sunk costs and institutional inertia. If illiberality in Turkey were tempered, it is possible that the accession progress could resume. However, what cannot be predicted are the critical junctures yet to happen. These could be endogenous - as a result of the political or economic collapse of the EU itself or a collapse resulting from pandemic. Alternatively, these could be exogenous factors concerning regional 
geopolitics (see also Reiners \& Turhan, Chapter 16). The accession process could restart if Turkey liberalized, but what we do not yet know is the severity of the events which could blow it off course once more.

\section{REFERENCES}

Amnesty International (2016). Press Release. EU Turkey summit: Don't wash hands of refugee rights. https://www.amnesty.org/en/latest/news/2016/ 03/eu-turkey-summit-refugees/. Accessed 28 Jun 2020.

Barker, A. (2015, October 15). Turkey offered sweeteners in exchange for migrants. The Financial Times. https://www.ft.com/content/14d828447293-1le5-bdbl-e6e4767162cc. Accessed 20 Nov 2020.

Barker, A., Acton, M., \& Brunsden, J. (2017, October 20). Brussels threatens to cut Turkey's accession funds. The Financial Times. https://www.ft.com/con tent/e0973740-b59e-11e7-a398-73d59db9e399. Accessed 20 Nov 2020.

Beesley, A. (2016, December 13). Austria calls for 'freeze' on EU-Turkey accession talks. The Financial Times. https://www.ft.com/content/50d788d6cl4c-1le6-81c2-f57d90f674la. Accessed 20 Nov 2020.

Bhaskar, R. (1989). Reclaiming reality: A critical introduction to contemporary philosophy. London: Verso.

Buzan, B., Wrever, O., \& Wilde, Jd (Eds.). (1998). Security: A new framework for analysis. Boulder: Lynne Rienner.

Candau, M. (2019, July 24). Turkey suspends deal with the EU on migrant readmission. Euractiv News. https://www.euractiv.com/section/globaleurope/news/turkey-suspends-deal-with-the-eu-on-migrant-readmission/. Accessed 20 Nov 2020.

Cappoccia, G., \& Kelemen, D. (2007). The study of critical junctures: Theory, narrative, and counterfactuals in historical institutionalism. World Politics, $59(3), 341-369$.

Collier, D. (2011). Understanding process tracing. Political Science and Politics, $44(4), 823-830$.

Collier, R., \& Collier, D. (1991). Shaping the political arena: Critical junctures, the labor movement, and regime dynamics in Latin America. Princeton: Princeton University Press.

Committee to Protect Journalists (2012). Turkey's press freedom crisis: The dark days of jailing journalists and criminalizing dissent. https://cpj.org/reports/ 2012/10/turkeys-press-freedom-crisis/. Accessed 24 Jun 2020.

Cortell, A., \& Peterson, S. (1999). Altered states: Explaining domestic institutional change. British Journal of Political Science, 29(1), 177-203.

Council of the European Union. (2006, December 11). 2770th Council meeting, general affairs and external relations. Press release. 16289/06 (Presse 352). Brussels. 
Council of the European Union. (2019). Turkish drilling activities in the Eastern Mediterranean: Council adopts conclusions. Press release. https://www.con silium.europa.eu/en/press/press-releases/2019/07/15/turkish-drilling-act ivities-in-the-eastern-mediterranean-council-adopts-conclusions/. Accessed 20 Nov 2020.

Dombey, D. (2011, September 19). Turkish gunship threat over gas drilling. The Financial Times. https://www.ft.com/content/ld33c952-e2ec-11e0-903d00144 feabdc0. Accessed 20 Nov 2020.

Esen, B., \& Gümüşçü, S. (2018). The perils of Turkish presidentialism. Review of Middle East Studies, 52(1), 43-53.

European Commission. (2005, October 3). Negotiating framework. Luxembourg. https://ec.europa.eu/neighbourhood-enlargement/sites/near/files/ pdf/turkey/st20002_05_tr_framedoc_en.pdf. Accessed 29 Jun 2020.

European Commission. (2012). Positive EU-Turkey agenda launched in Ankara. MEMO/12/359. Brussels, 17 May.

European Commission. (2014, October 1). Statement of commissioner Malmström on the entry into force of the readmission agreement between Turkey and the EU. STATEMENT/14/285. Brussels.

European Commission. (2016) Press release. EU-Turkey statement: Questions and answers. https://ec.europa.eu/commission/presscorner/detail/ en/MEMO_16_963. Accessed 30 May 2020.

European Commission. (2019, May 29). Turkey 2019 report. SWD(2019) 220 final. Brussels.

European Council. (2015, November 29). Meeting of the EU heads of state or government with Turkey. https://www.consilium.europa.eu/en/meetings/ international-summit/2015/11/29/. Accessed 29 Nov 2020.

European Council. (2016, March 18). EU-Turkey statement. Press release. https://www.consilium.europa.eu/en/press/press-releases/2016/03/18/ eu-turkey-statement/. Accessed 27 Nov 2020.

European Parliament. (2019, March 13). Parliament wants to suspend EU accession negotiations with Turkey. Press release. 20190307 IPR30746.

George, A., \& Bennett, A. (2005). Case studies and theory development in the social sciences. Massachusetts: MIT Press.

German Marshal Fund. (2014). Transatlantic trends-Key findings 2014. https://www.gmfus.org/sites/default/files/files/1408726801Trends_2014_ complete.pdf. Accessed 22 Nov 2020.

Gorges, M. (2001). The new institutionalism and the study of the European Union: The case of the social dialogue. West European Politics, 24(4), 152168.

Gourevitch, P. (1986). Politics in hard times. Ithaca: Cornell University Press.

Hall, P. A., \& Taylor, R. C. R. (1996). Political science and the three new institutionalisms. Political Studies, 44(5), 936-957. 
Hannay, D. (2005). Cyprus: The search for a solution. London: I.B. Tauris.

Hay, C. (2002). Political analysis. Basingstoke: Palgrave.

Kaya, A. (2021). Europeanization and de-Europeanization of Turkish asylum and migration policies. Chapter 14 , in this volume.

Krasner, S. (1984). Approaches to the state: Alternative perceptions and historical dynamics. Comparative Political Studies, 16(2), 223-246.

Mahoney, J. (2000). Path dependence in historical sociology. Theory and Society, $29(4), 507-548$.

Mahoney, J. (2001). Legacies of Liberalism: Path dependence and political regimes in Central America. Baltimore: John Hopkins University Press.

March, J., \& Olsen, J. (1984). The new institutionalism: Organisational factors in political life. American Political Science Review, 78(3), 734-749.

Martin, N. (2015a). Security and the Turkey-EU accession process. London: Palgrave.

Martin, N. (2015b). How the EU came to open accession negotiations with Turkey: The role of the 'well-placed Brits'. Journal of European Integration History, 21(2), 231-249.

Martin, N. (2018). The A. K. party and the Kurds since 2014: A discourse of terror. British Journal of Middle Eastern Studies, 45(4), 543-558.

Martin, N. (2019). From containment to realpolitik and back again: A realist constructivist analysis of Turkey-EU relations and the migration issue. Journal of Common Market Studies, 57(6), 1349-1365.

Moravcsik, A. (1999). The choice for Europe: Social purpose and state power from Messina to Maastricht. London: UCL Press.

Parker, G., Dombey, D., \& Thornhill, J. (2007, June 12). France in threat to Turkey's EU hopes. The Financial Times. https://www.ft.com/content/56d c5846-19le-11dc-a961-000b5df10621. Accessed 20 Nov 2020.

Parker, G., \& Thornhill, J. (2007, June 25). France blocks Turkey eurozone talks. The Financial Times. https://www.ft.com/content/734c22e4-2342$11 \mathrm{dc}-9 \mathrm{e} 7 \mathrm{e}-000 \mathrm{~b} 5 \mathrm{df} 10621$. Accessed 20 Nov 2020.

Paul, A. (2012). The AK Party model for Islamists toward an independent Kurdistan? Turkey and the EU: A positive agenda. Insight Turkey, 14(3), 25-33.

Peters, B. G., Pierre, J., \& Kings, D. S. (2005). The politics of path dependency: Political conflict in historical institutionalism. Journal of Politics, 65(4), 12751300.

Pierson, P. (1994). The path to European integration: A bistorical institutionalist perspective. (Program for the study of Germany and Europea working paper No. 5.2, 25 October). http://aei.pitt.edu/63633/1/PSGE_WP5_2. pdf. Accessed 27 Nov 2020.

Pierson, P. (2004). Politics in time. Princeton: Princeton University Press. 
Pierson, P., \& Skocpol, T. (2002). Historical institutionalism in contemporary political science. In I. Katznelson \& H. V. Milner (Eds.), Political science, state of the discipline (pp. 693-721). New York: W. W. Norton \& Company.

Pitel, L. (2016, March 8). EU-Turkey refugee deal: UN and Amnesty attack 'short-sighted and inhumane' plan. The Independent. https://www.indepe ndent.co.uk/news/world/europe/eu-turkey-refugee-deal-un-and-amnestyattack-short-sighted-and-inhumane-plan-a6919966.html. Accessed 20 Nov 2020 .

Pitel, L. (2017, September 6). Erdoğan dares Brussels to kill EU accession talks. The Financial Times. https://www.ft.com/content/1285e646-930a11e7-a9e6-11d2f0ebb7f0. Accessed 20 Nov 2020.

Pitel, L. (2019, July 16). Turkey vows to continue drilling for gas despite EU sanctions. The Financial Times. https://www.ft.com/content/9d0fe410a7b7-11e9-984c-fac8325aaa04. Accessed 20 Nov 2020.

Pitel, L., \& Beesley, A. (2015, November 22). EU bows deeply to Erdoğan in bid to relieve migrant crisis. The Financial Times. https://www.ft.com/con tent/0410ec50-9113-11e5-bd82-clfb87bef7af. Accessed 20 Nov 2020.

Pitel, L., \& Brunsden, J. (2016, August 9). Blow for migrant deal as Turkey rejects EU terror law demands. The Financial Times. https://www.ft.com/ content/48882f9a-5d48-11e6-a72a-bd4bfl198c63. Accessed 20 Nov 2020.

Reilhac, G. (2019, March 13). EU Parliament calls for freeze on Turkey's membership talks. Reuters Press Agency. https://uk.reuters.com/article/ uk-eu-turkey/eu-parliament-calls-for-freeze-on-turkeys-membership-talks-idU KKCN1QU2LE. Accessed 20 Nov 2020.

Reiners, W., \& Turhan, E. (2021). Current trends and future prospects for EUTurkey relations: Conditions for a cooperative relationship. Chapter 16, in this volume.

Rixen, T., \& Viola, L. (2016). Towards explaining change and stability in international institutions. In T. Rixen, L. A. Viola, \& M. Zürn (Eds.), Historical institutionalism and international relations: Explaining institutional development in world politics (pp. 3-35). Oxford: Oxford University Press.

Sewell, W. H. (1996). Three temporalities: Toward an eventful sociology. In T. J. McDonald (Ed.), The historic turn in the human sciences (pp. 245-280). Michigan: University of Michigan Press.

Skocpol, T. (1979). States and social revolutions: A comparative analysis of France, Russia and China. Cambridge: Cambridge University Press.

Smith, H. (2015, September 4). Aylan Kurdi: Friends and family fill in gaps behind harrowing images. The Guardian. https://www.theguardian.com/ world $/ 2015 /$ sep $/ 03 /$ refugee-crisis-friends-and-family-fill-in-gaps-behind-har rowing-images. Accessed 20 Nov 2020. 
Steinmo, S. (2008). What is historical institutionalism? In D. Della Porta \& M. Keating (Eds.), Approaches in the social sciences (pp. 118-138). Cambridge: Cambridge University Press.

Steinmo, S., Thelen, K. A., \& Longstreth, F. (Eds.). (1992). Structuring politics: Historical institutionalism in comparative analysis. Cambridge: Cambridge University Press.

Turhan, E. (2016). Turkey's EU accession process: do member states matter? Journal of Contemporary European Studies, 24(4), 463-477.

Turhan, E., \& Reiners, W. (2021). Unpacking the new complexities of EUTurkey relations: Merging theories, institutions, and policies. Chapter 1, in this volume.

Turhan, E., \& Wessels, W. (2021). The European Council as a key driver of EU-Turkey relations: Central functions, internal dynamics and evolving preferences. Chapter 8 , in this volume.

United Nations. (2017). Office of the high commissioner for human rights. Report on the human rights situation in south-east Turkey July 2015-December 2016. https://www.ohchr.org/documents/countries/tr/ohchr_south-east_t urkeyreport_10march2017.pdf. Accessed 30 Jun 2020.

Wagstyl, S., \& Chazan, G. (2017, September 3). Merkel says Turkey 'should not become an EU member'. The Financial Times. https://www.ft.com/con tent/cf9f2566-90cc-11e7-a9e6-11d2f0ebb7f0. Accessed 20 Nov 2020.

Wight, C. (2006). Agents, structures and international relations: Politics as ontology. Cambridge: Cambridge University Press.

Gülay Icoz is an independent researcher who received her Ph.D. from Royal Holloway, University of London. Her work encompasses the Turkey-EU relationship as well as British politics and issues of the rule of law in Poland and Hungary. Icoz blogs at ideasoneurope.eu and has published on Turkey's relationship with the EU in the Journal of Contemporary European Studies in 2016 and 2011. She also co-edited a special issue for the same journal in 2016 entitled 'Opportunities Missed: Turkey-EU Accession since 2005'. Icoz was a local councillor in the UK between 2006 and 2014.

Natalie Martin is assistant professor at the University of Nottingham in the UK. She was a BBC journalist before returning to academia to do a Ph.D. on Turkey's EU accession process and received her Ph.D. from Loughborough University in 2012. She has since published widely on the issue of Turkey and the EUand more recently has examined the role of liberal democracy and the media in both Turkey and the UK. She is part of the organizing council of the British 
Association for Turkish Area Studies (BATAS) and a trustee of the British Institute at Ankara (BIAA). Her most recent book is The Securitisation of News in Turkey: Journalists as Terrorists? (2020) which is part of the international political communication series of Palgrave Macmillan.

Open Access This chapter is licensed under the terms of the Creative Commons Attribution 4.0 International License (http://creativecommons.org/licenses/ by $/ 4.0 /)$, which permits use, sharing, adaptation, distribution and reproduction in any medium or format, as long as you give appropriate credit to the original author(s) and the source, provide a link to the Creative Commons license and indicate if changes were made.

The images or other third party material in this chapter are included in the chapter's Creative Commons license, unless indicated otherwise in a credit line to the material. If material is not included in the chapter's Creative Commons license and your intended use is not permitted by statutory regulation or exceeds the permitted use, you will need to obtain permission directly from the copyright holder.

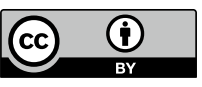

